pointed. The leaves broad oval, not narrowed towards the emarginate apex; the primary veins nine on each side the central one; on the back of the leaf convex, soft; secondary veins concave on both sides.-J. DE C. S.

\title{
ON THE STRUCTURE OF THE BELEMNITE.
}

\section{To the Editors of the Annals of Natural History.}

Gentlemen,-When a disputant affirms a statement ' most emphatically,' it may be suspected that the emphasis is added to supply the want of inherent truth. This is the case with Dr. Mantell when he so affirms that the "phragmocone is common to numerous genera of Cephalopods," - a statement which is made to appear true only by attaching to the term 'phragmocone' a meaning peculiar to the asserter. A 'conical chambered siphunculated shell' is no doubt common to numerous genera of Cephalopods : before Owen's anatomy of the Nautilus, Belemnites, and Spirula, it was deemed to characterize all that section of the class which Cuvier grouped together under the wide Linnæan term of Nautilus, and with which the "Siphonifera" of Férussac and D'Orbigny is synonymous. The term 'phragmocone' was first proposed by Professor Owen, and applied by him to a particular modification of the 'conical chambered siphunculated shell'; to that viz. in which the cone is short and straight, the chambers, very shallow, and rapidly enlarging, uniformly concave towards the outlet, with the siphuncle marginal and ventral, and the whole invested by a partly horny, partly calcareous layer continuous with the sheath protecting the more advanced parts of the Belemnite (Phil. Trans. 1844, pp. 68, 69). This modification of the 'conical chambered siphunculated shell' is common to all the subgenera into which the 'Belemnites' of Cuvier have since been divided, and it is 'peculiar' to them.

The most variable and therefore least important part of their complex shell is the 'dart,' ' guard,' or 'osselet'; its different forms and proportions afford, indeed, the characters of most of the species, and in the Bel. brevissima, Duv., e. g., it is reduced to the size of the similarly solid calcareous terminal mucro of the shell of Beloptera, Sepia, \&c., to which, according to Cuvier, Buckland, and other eminent naturalists, it is answerable. So much, therefore, for Dr. Mantell's other affirmation that the part which he chooses to call 'osselet' is the essential part or character of the Belemnite. I shall not trespass on your space by any notice of Dr. Mantell's views of the value of Professor Owen's researches on the extinct Cephalopods possessing the 'phragmacone,' or of my own opinion of the influence of the Professor's works in general on the progress of Comparative Anatomy : and I limit myself to a single sample of the nature of the discoveries to which Dr. Mantell vaunts his peculiar claims. The part, e. g., which he calls the capsule or sheath is the part so called by Buckland, together with other parts subsequently pointed out by Owen. The author of the 6th Bridgewater Treatise (p. 372) describes"A conical thin horny sheath, or cup, commencing from the base of 
the hollow cone of the fibro-calcareons sheath, and enlarging rapidly as it extends outwards to a considerable distance. This horny cup formed the anterior chamber of the Belemnite, and contained the ink-bag and some of the viscera." Owen subsequently traced a similarly organized membrane continued backwards from the margin of the alveolus, where Buckland's 'capsule' commences, " to line the alveolar cavity of the spathose guard," and to cover the exterior surface of the guard itself ; the first description of which latter structure we find in the following words of his memoir, 'Phil. Trans.' 1844, p. 69 :- "The exterior surface of the spathose guard of the Belemnites of the Oxford clay, though smoother than in some other species, is minutely granular, and occasionally presents faint traces of vascular impressions, proving it to have been invested by an organized membrane of the living Cephalopods." With his usual cautious exactitude he forbears to extend to this investing organized membrane the term 'capsule,' which his predecessor had correctly restricted to that part which, so far as it truly performs the function of a capsule, commences, as Dr. Buckland describes, where the fibro-calcareous sheath terminates. Every fact has its value; but this varies indefinitely, and does not become greater, when, by an abuse of terms, a small particular is laid claim to by a self-asserted discoverer.

I am, Gentlemen, your obedient servant,

The Quarterly Reviewer.

\section{METEOROLOGICAL OBSERVATIONS FOR JUNE 1852.}

Chiswick.-June 1. Clear and fine. 2. Cloudy : fine: rain. 3. Cloudy. 4. Overcast : fine : clear. 5. Very fine : slight rain. 6. Rain : clear at night. 7. Constant rain. 8. Thick whitish haze: low fog in the evening: heavy rain. 9. Excessively heavy rain throughout. 10. Rain: cloudy : clear. 11. Overcast. 12. Slight rain : overcast. 13. Fine: rain at night. 14. Showery. 15. Fine: showery : clear. 16. Rain: uniformly overcast. 17. Cloudy throughout. 18. Rain : showery : heavy rain. 19. Heavy clouds : clear and fine. 20. Overcast : rain. 21. Rain : cloudy. 22-24. Fine. 25. Uniformly overcast : fine : rain at night. 26. Rain: heavy showers. 27. Overcast: heavy showers. 28. Fine: densely overcast. 29. Overcast : cloudy : clear. 30. Fine : rather windy : clear at night.-More rain fell on the $7 \mathrm{th}, 8 \mathrm{th}$, and $9 \mathrm{th}$, than on any three consecutive days for at least twenty-six years near London.

Mean temperature of the month ............................ $58^{\circ} \cdot 01$

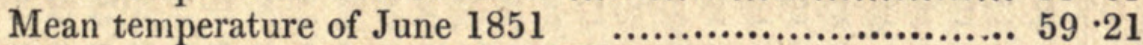

Mean temperature of June for the last twenty-six years $\ldots 60 \cdot 61$

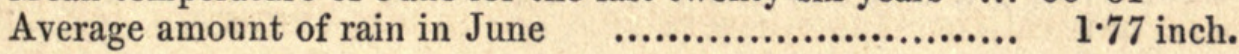

Boston.-June 1. Fine. 2. Fine: rain P.M. 3. Cloudy: rain A.M. 4. Fine rain A.M. 5. Fine. 6. Rain : rain A.M. 7, 8. Cloudy. 9. Cloudy : rain A.M: 10, 11. Cloudy : rain A.M. and P.M. 12. Cloudy : rain A.M. 13. Cloudy : rain F.M. 14, 15. Cloudy : rain A.M. and P.M. 16. Rain : rain A.M. and P.M. 17. Fine. rain A.M. and P.M. 18, 19. Cloudy : rain A.M. 20. Cloudy : rain P.M. 21. Rain : rain A.M. 22. Cloudy : rain A.м. and P.M. 23-25. Fine. 26. Cloudy : rain A.M.: 27. Cloudy. 28. Cloudy : rain P.M. 29, 30. Cloudy.

Sandwick Manse, Orkney.-June 1, 2. Showers. 3. Rain: showers. 4, 5. Bright : clear : fine. 6. Hazy. 7. Hazy : clear : fine. 8. Bright: fine. 9. Cloudy : damp. 10. Drizzle. 11. Drizzle : showers. 12. Damp : bright. 13. Clear : fine : cloudy. 14. Showers : cloudy : fine. 15. Bright: fine : clear : fine. 16. Bright : fine : cloudy. 17. Clear : fine : cloudy. 18. Damp : fog. 19. Bright : clear : fine. 20. Damp. 21. Damp : fog. 22,23. Rain. 24, 25. Bright: showers. 26. Bright: rain. 27. Bright: showers: fine. 28. Clear: fine: drops : fine. 29. Clear : fine : cloudy : fine. 30 . Rain. 


\section{$2 \mathrm{BHL}$ Biodiversity Heritage Library}

1852. "On the structure of the Belemnite." The Annals and magazine of natural history; zoology, botany, and geology 10, 158-159.

https://doi.org/10.1080/03745485609495669.

View This Item Online: https://www.biodiversitylibrary.org/item/19400

DOI: https://doi.org/10.1080/03745485609495669

Permalink: https://www.biodiversitylibrary.org/partpdf/10698

\section{Holding Institution}

Natural History Museum Library, London

\section{Sponsored by}

Natural History Museum Library, London

\section{Copyright \& Reuse}

Copyright Status: Public domain. The BHL considers that this work is no longer under copyright protection.

This document was created from content at the Biodiversity Heritage Library, the world's largest open access digital library for biodiversity literature and archives. Visit BHL at https://www.biodiversitylibrary.org. 